\title{
Research on the Cultivation of Business Culture Awareness in Business English Teaching
}

\author{
Wang Yuanhang \\ Shi Jiazhuang University of Applied Technology, Shi Jiazhuang City,Hebei Province
}

Keywords: Cultivation, Business Culture Awareness, Business English Teaching

\begin{abstract}
Cultural factors penetrate in international business activities and they play a very important role. Whether it can cross cultural barriers and avoid cultural conflicts, which is the key to the smooth development of international business activities. This paper analyzes the obvious business culture conflict in international business activities, clarifies the importance of strengthening the cultivation of business culture consciousness in business English teaching, and puts forward some suggestions on strengthening the awareness of business culture.
\end{abstract}

\section{Introduction}

The cultivation of healthy business culture consciousness is the most important thing in business English teaching. If only language learning and light culture learning, not only hinder language learning, but also not conducive to different countries, the exchange between different ethnic groups, and ultimately not conducive to the development of their own nation. Therefore, cultivating healthy business culture consciousness is one of the important tasks and goals of business English teaching.

In business English teaching, some English teachers only pay attention to English language knowledge and skills, while ignoring the business culture, so that language and culture out of touch. Although many students have good knowledge of language knowledge, vocabulary is also very large, the basic skills of language is not bad, but to the actual business communication, because of the lack of business culture knowledge, with the language of the language of the language of communication standards, A joke. For example, punctual standards are quite different in different cultures. Americans have a strong sense of time, and they are never late for the appointment; and the Chinese who are accustomed to appointing a few minutes later may have trouble with the Americans. The teaching mode of the heavy language and light culture is unfavorable to the cultivation of the comprehensive quality of the business English majors. Facts show that language and culture are inseparable and interdependent. Language is both a carrier of culture and an important medium of culture. Business English as a specialized use of English contains a wealth of business culture. Therefore, business English teaching must include business culture teaching, cultural knowledge teaching and language knowledge and skills teaching should be carried out at the same time. Only in this way, we can learn both authentic business English, but also to develop healthy business culture awareness.

\section{The Importance of Cultivating Business Culture Consciousness in Modern Business English Teaching}

The term business English was developed and developed in the 1980s, and its teaching and research was mainly initiated by China in the 1990s and quickly developed into international business English, which has now become the basic course of our tertiary institutions.

At this stage, with the rapid development of social economy, the exchanges and cooperation with the Western countries of China, whether in the economy or in education and other aspects are more and more frequently. Modern society on the requirements of foreign language talent is to have a solid 
language foundation, high level of professional knowledge, application ability. Business English teaching has three core objectives of teaching subsystem, that is, business background knowledge, business background used in the language, business communication skills; which, in order to accurately determine the content of business background knowledge and how much weight in the course, It is necessary to see the nature of the work of the relevant learners and professional level. The language used in the business background mainly covers the vocabulary, voice, intonation, chapter and other aspects of the ability. Business communication skills mainly to participate in business communication activities must master the skills, not only related to the language class skills, but also non-language class skills. Although the target teaching subsystem covers all aspects of business English, but the actual classroom teaching process, some educators still remain in the business context of English to use the English vocabulary, voice, text, grammar understanding, which led to the language class teaching is too strong, and in non-linguistic categories such as the cultural level of knowledge is often overlooked. Most of the students in the learning process is very hard, but also through the business English class examinations, and made the certificate, but these most of the students during the school performance into the post, but faced with the difficulties of communication difficulties. Although they fully grasp and understand the language knowledge, vocabulary, language basic skills are relatively good. However, when they are really engaged in business communication, but because of the lack of business culture knowledge, through the language of the nation's language communication, and ultimately lead to misunderstanding and the occurrence of conflict, business activities did not proceed smoothly. In addition, other aspects of business activities such as the packaging of goods, if the goods with a lotus pattern of goods sold to Japan, the pig-shaped pattern of goods shipped to the Islamic countries, the ingredients do not have Chinese herbal medicines to the United States will fail end. The above-mentioned business culture phenomenon is common in business activities.

\section{The Differences in Business Culture}

The existence of time cultural differences. The main reasons for the existence of cultural differences are: geographical reasons, religious reasons and historical reasons. The customs of the national culture, the value orientation, behavior habits are not the same, and in business transactions, these details of the stage of its success or not played a decisive role. There is a large cultural difference in the transaction side, for the details of the embodiment of great attention. Therefore, the degree of business culture literacy in cross-cultural business process has a very important position. Business English business culture in the international business activities in the existence of the differences in business culture embodied in the views of different countries are inconsistent, and with the different views continue to accumulate, into a business culture differences at the same time seriously affect the business activities of the normal development.

The business values differences. Chinese culture is mainly a kind of collectivism culture, and Western culture belongs to individualism can be in the process of commercial negotiation to find the existence of different. Business negotiation is the most important and important part of business activities, which directly determines the continuous and healthy development of business activities. Because each country's political and economic situation and cultural habits are different, so the stakeholders should carefully observe the cultural values of the object of discussion in order to prevent the occurrence of cultural conflict. Such as, Japanese businessmen to participate in business negotiations will be presented with each other gifts, which think this is the best way to represent the friendly and courteous. From the relevant survey, the United States individualism values are extremely strong occupies the top, followed by Australia, Britain, Canada. The United States felt the courage to be responsible for the embodiment of a positive spirit, so the United States negotiators generally have real power. China or Japan adopted the form of negotiations is completely different, in the decision-making will be through collective bargaining or voting the way to the final decision. If the individual decision-making, then it will be as a private proposition, there is no superior leadership and the entire team staff in the eyes. 
The differences of management. Business culture, the impact of a certain extent, will affect the business management; at present, with the rapid development of world trade, enterprises have carried out a lot of cross-border transactions, and from the country's personnel management culture and business are different. However, the business management and culture there is a close relationship, so we must not blindly copy the other countries to develop the management methods, should be combined with their own actual situation to the corresponding choice, if the lack of scientific and rational management, it will seriously cause the loss of economic benefits, and the interests of employees will have a certain impact.

\section{The Cultivation of Business Culture Consciousness in Business English Teaching}

Improve the cultural literacy of business English teachers. First of all, teachers have a clear understanding of teaching tasks. Clear the purpose of teaching the subject, that is, according to different cultural environment and business activities under the conditions of English foreign talent. Teachers to actively create conditions, purposeful in the teaching into the concept of business culture, at the same time to further enhance their cultural heritage, a more systematic understanding of English-speaking countries, social system, cultural background, business activities and management measures to better guide students compare their mother tongue, find their own different, to avoid errors in business communication. Teachers a good guide to the role of students can improve the efficiency of learning a lot play a role in the effect of half effect.

Strengthen the teaching of business English teaching materials. Improve teaching quality, teaching material is very important. In determining the teaching objectives, teaching methods and means later, the preparation of teaching materials and some can not keep up, we must strengthen the construction of teaching materials. It can be prepared according to the social development of the characteristics of the times in line with the characteristics of the teaching materials in the process of preparation to grammar as the main line, with language throughout the teaching materials to achieve the ability of students to express language for the purpose of integration into different cultures in the text of ideas. In the choice of teaching materials should pay attention to close to life, select some vivid, typical examples to enrich the content. As much as possible to select some of the more practical cases at the same time its interpretation, to stimulate students' interest in learning and cultural awareness, in order to help them establish confidence in business activities, training analysis of thinking ability, pay attention to their words and deeds, for the future business Work to lay a solid foundation. But also the English film and television works into the textbooks, so that students can not only directly understand the foreign social and cultural conditions, through the combination of graphic more conducive to students to learn English culture learning and mastery. With this form can enrich the content of teaching materials, set language, skills and practicality in one, to promote students to better learn language and culture, better integrated into the English environment. The design of the mission material should be derived from the real social life. The ultimate goal of our study of business English is to apply, not to take exams. Therefore, in the daily oral practice, the teacher on the practice of the scene environment should be based on specific business activities to carry out simulation training. For example, to find some classic business speech video, so that students of Chinese-English translation, and lists the video appeared in the high-frequency business English vocabulary, so that students can feel the practicality of business English, not only enrich the textbook content, but also to enhance the students' desire to learn. Through this way not only can students in the future business activities can effectively face a variety of situations, but also to make classroom teaching become lively and interesting, so that students can be integrated into the teaching activities.

Innovate the ways of business English teaching. Teachers in the classroom activities should not "spoon" teaching, but not "full house irrigation", to play the characteristics of business English teaching. In the teaching to be flexible, so that the whole classroom is full of fun and vivid. For example, you can use case analysis to promote the development of students' ability to analyze, so that a better solution to the problems encountered in learning. You can also use the "role-playing" form, so that students in a specific situation to practice. Such as simulating a business event, the theme is a 
business product conference. In the conference need to chairman, product director, marketing director and host and other different roles, each group invited several students to play. Teachers to each student a note, the content is the role of these roles and tasks, and then let the students according to their roles held conference, through product introduction, the media Q \& A way. Through this way not only can students in the future business activities can effectively face a variety of situations, but also to make classroom teaching become lively and interesting, so that students can be integrated into the teaching activities.

Combined with the actual teaching to design the teaching business scenarios. In business English teaching activities, the design of business scenarios can attract students' attention. Scenic design can be a variety of ways, students have not yet come into contact with the business scene, the creation of business scenarios can be based on materials on the material to the students began to become familiar with the business scene, the business English teachers can guide students to create business scene, you can find some of the existing classic scenes, and finally students to master the business scene created by the students themselves to create business scenarios. When creating a business scenario, let the students be able to participate in their own hands and fully motivate them. For the role of business scenarios, business English teachers must remind students to pay attention to the role of the business culture. For example: If you create a business negotiation between China and the United States for business negotiations, Chinese business negotiations for the US side of the commodity price cuts will not be a positive solution to the problem, the Chinese side will not directly disagree or agree with the words. This time will let the United States side do not understand, do not know the Chinese side in the end is agreed or do not agree, the final negotiations may fail. Business English teachers in the creation of business scenarios played a great role in the creation, the need to remind students to pay attention to the role of cultural situation, after the creation, but also to make a comment on the students play the situation, first of all to ensure that students do the work and then in the process of playing the shortcomings and mistakes to make judgments, so that students timely correction.

With the help of multimedia to improve students' cross-cultural awareness of special training. 1) Case study: the use of business activities in some of the classic examples of research, inferred, so that students fully participate in the discussion, and put forward their own views, so as to fully understand the local and foreign culture is different. 2) Personally experience: with the role of conversion and field work (field work), create a cultural atmosphere, so that students in such an atmosphere to master the ability to deal with a variety of emergencies, while the English culture can understand and enhance their culture literacy. 3) Information introduction: Take audio and video data or reading, etc., consciously introduce foreign business culture, or hire other foreign scholars to school lectures or cultural exchanges, so as to introduce students to a variety of English culture, while mastering some communication skills.

\section{Conclusion}

In summary, at present, with the rapid development and progress of society, business and cultural activities will be increasingly frequent, and business English is because of the addition of business culture factors become more rich, business culture activities not only to students of international business English communication ability to cultivate, but also let the students know that fully grasp and understand the key business culture knowledge directly determines the success of the transaction or not. In order to cultivate business English professionals suited to the needs of modern society, students should be made aware of the importance of business culture, so as to establish a good sense of business culture in business English teaching. 


\section{References}

[1] D.M.JIN. Cultivation of Business Culture Consciousness in Cultural Patch Teaching, J. Journal Weekly, 2008 (38)

[2] S. Y. Cao. Based on the needs of regional economic development to build business English professional talent training model, J. Education and occupation, 2011 (6)

[3] Y. Wang. New Century College English Reading Course Culture Volume, J. Shanghai: Shanghai Science and Technology Education Press, 2003.

[4] S. Liang. Chinese and Western cultural differences and business English teaching, J. Heilongjiang Foreign Trade, 2011 (10)

[5] F.F. Jiao. Business English teaching in cross-cultural awareness of the training, J. Jiamusi Education College, 2010 (2)

[6] J. Zheng. Business English negotiation in the embodiment of business culture awareness, J. Jiamusi Education College, 2010 (l) 